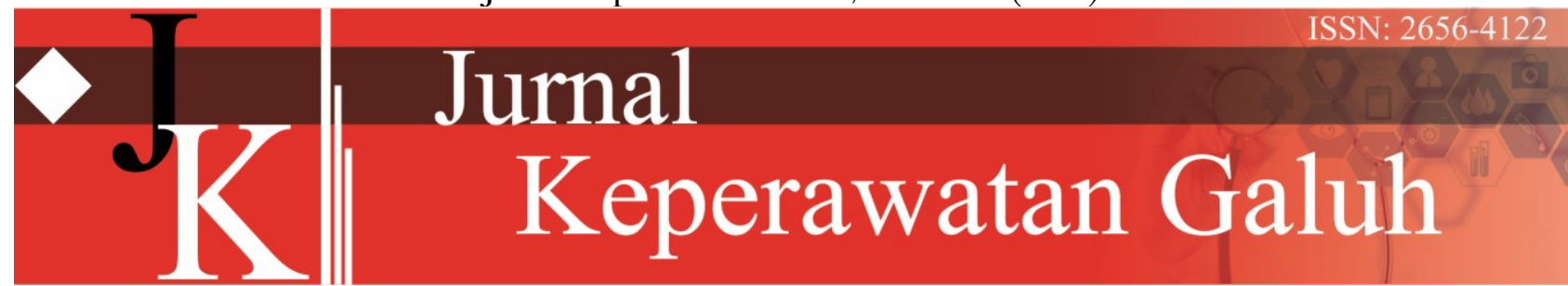

https://jurnal.unigal.ac.id/index.php/JKG/article/view/4533

\title{
HUBUNGAN TINGKAT PENGETAHUAN IBU TENTANG IMUNISASI CAMPAK DENGAN KETERCAPAIAN IMUNISASI CAMPAK DI WILAYAH KERJA PUSKESMAS CIPAKU KABUPATEN CIAMIS TAHUN 2020
}

\author{
Dini Nurbaeti Zen ${ }^{1}$, Dea Restu Ramdani ${ }^{2}$ \\ ${ }^{1,2}$ Program Studi Ilmu Keperawatan Universitas Galuh, Indonesia \\ (Sejarah artikel: Diserahkan Mei 2020, Diterima Juni 2020, Diterbitkan Juli 2020)
}

\begin{abstract}
ABSTRAK
Penyakit campak merupakan penyakit menular yang masih menjadi masalah kesehatan bayi dan anak. Campak juga merupakan penyakit endemik di negara berkembang salah satunya di Indonesia yang masih menempati urutan ke-5 penyakit yang menyerang pada bayi dan balita. Penyakit campak termasuk penyakit yang dapat dicegah dengan tindakan imunisasi dan mendapat perhatian lebih dari pemerintah karena Indonesia ikut serta dalam program eliminasi campak pada tahun 2020 dengan cakupan campak minimal 95\% di setiap wilayah secara merata. Kemenkes RI menjelaskan terkait cakupan imunisasi itu berhubungan erat dengan pengetahuan dan sikap keluarga akan manfaat dari imunisasi. Semakin tinggi pengetahuan dan sikap semakin tinggi pula angka cakupannya.Penelitian ini menggunakan desain penelitian deskriptif korelasi dengan pendekatan cross sectional, jenis penelitian ini tujuannya untuk menemukan ada atau tidaknya hubungan antara tingkat pengetahuan ibu tentang imunisasi campak dengan ketercapaian imunisasi campak pada bayi. Sampel yang digunakan yaitu berjumlah 88 orang Ibu yang memiliki bayi. Teknik pengambilan sampel dalam penelitian ini adalah proportionate stratified random sampling. Pada pengambilan data yaitu dengan memberikan kuesioner dan lembar observasi. Untuk Uji statistik pada penelitiam ini menggunakan product moment. Hasil penelitian menunjukan terdapat hubungan antara tingkat pengetahuan ibu tentang imunisasi campak dengan ketercapaian imunisasi campak pada bayi di Puskesmas Cipaku Kabupaten Ciamis Tahun 2020 dengan nilai $\rho$ value $<\alpha(0,000<0,05)$. Saran dari penelitian ini diharapkan bagi instansi kesehatan, tenaga kesehatan terutama orang tua lebih meningkatkan kembali kegiatan yang berhubungan dengan kesehatan khususnya imunisasi campak dan mempertahankan pengetahuan ibu tentang imunisasi campak dengan baik
\end{abstract}

Kata Kunci: Pengetahuan Ibu, Ketercapaian Imunisasi Campak, Bayi

\section{PENDAHULUAN}

Imunisasi dasar adalah pemberian imunisasi awal pada bayi untuk mencapai kadar kekebalan di atas ambang perlindungan ( Depkes RI 2012). Setiap bayi wajib mendapatkan imunisasi dasar lengkap (IDL) yang terdiri dari 1 dosis BCG, 3 dosis DPT, 4 dosis polio, 3 dosis hepatitis B, dan 1 dosis campak. Imunisasi BCG dapat mencegah serangan penyakit tuberkulosis (TB) pada paru paru. Imunisasi DPT (difteri,pertusis,tetanus) dapat mencegah ketiga penyakit mematikan pada bayi yaitu difteri penyakit yang membuat bayi sulit bernafas, lumpuh dan alami gagal jantung, pertusis penyakit batuk rejan yang sangat parah hingga tak bisa bernafas, tetanus penyakit yang mengakibatkan kaku otot dan mulut mengunci.
Imunisasi Polio untuk mencegah penyakit yang dapat menyebabkan kelumpuhan permanen. Imunisasi Hepatitis B $(\mathrm{Hb})$ dapat mencegah penyakit hepatitis $\mathrm{B}$ yang merupakan penyakit pada organ hati. Imunisasi campak untuk mencegah penyakit yang dapat menyebabkan demam tinggi, ruam, kebutaan dan kematian (Kemenkes RI, 2019).

Penyakit campak merupakan spenyakit menular yang masih menjadi masalah kesehatan bayi dan anak. Menurut WHO angka campak tertinggi ditemukan di Asia Tenggara yaitu sebesar $85 \%$ diikuti oleh Afrika yaitu sebesar 36\%. (WHO,2012). Penyakit campak disebabkan oleh virus golongan Paramyxovirus. Pada tahun 2013, di dunia terdapat 145.700 orang meninggal akibat 
Jurnal Keperawatan Galuh, Vol.2 No.2 (2020) 53 - 60

campak, sedangkan sekitar 400 kematian setiap hari sebagian besar terjadi pada bayi dan balita (WHO, 2015).

Virus campak disebakan oleh mikroorganisme yang dapat menular dari individu satu ke individu lain, utamanya pada anak yang memasuki usia pra sekolah dan tamat SD. Campak merupakan penyakit menular yang sering menyebabkan terjadinya Kejadian Luar Biasa (KLB). Campak adalah anggota dari Paramyxoviriade, dalam genus Morbillivirus. Penyakit campak mudah menular melalui pernafasan, terutama percikan ludah atau cairan yang keluar dari sistem pernafasan , seperti pada saat bersin,batuk, maupun berbicara. ( Kemenkes RI, 2017 ).

Campak juga merupakan penyakit endemik di negara berkembang salah satunya di Indonesia. Dimana, campak masih menempati urutan ke-5 penyakit yang menyerang terutama pada bayi dan balita. Pada tahun 2014 di Indonesia ada 12.944 kasus campak. Angka ini lebih tinggi dibandingkan pada tahun 2013 sebanyak 11. 521 kasus (Kemenkes RI 2015).

Kasus campak menyebar di daerah yang memiliki penduduk padat. Penyebaran kasus campak paling banyak terjadi di negara berkembang, salah satunya di Indonesia. Kejadian campak di Indonesia cenderung meningkat pada tahun 2016, yaitu sebanyak 12.681 kasus, dengan Incidence Rate ( IR ) sebesar 5 per 100.000 penduduk dan terdapat 1 kasus meninggal yang berasal dari Provinsi Jawa Barat. Jumlah tersebut lebih tinggi dari tahun sebelumnya, tahun 2015 yaitu sebesar 10.655 kasus, dengan IR sebesar 3,20 per 100.000 penduduk. Jumlah kasus campak pada tahun 2014 lebih tinggi dari pada tahun 2015, yaitu sebesar 12.944 kasus, dengan IR sebesar 5,13 per 100.000 penduduk ( Kemenkes RI, 2017).

Untuk persentase cakupan imunisasi campak pada bayi di Indonesia dari tahun 2015 - 2018 mengalami naik turun dengan persentase pada tahun 2015 yaitu $(92,3 \%)$, tahun $2016(93,0 \%)$, tahun 2017(91,8\%), dan tahun 2018 (92\%). Sedangkan untuk persentase cakupan imunisasi campak pada bayi menurut Riskesda ada 19 provinsi yang masih dibawah target ketercapaian dari 95\% salah satunya yaitu di Jawa Barat hanya (92,8\%). (Kemenkes RI, 2019).

Penyakit campak termasuk penyakit yang dapat dicegah dengan tindakan imunisasi. Salah satu bentuk program imunisasi yang dilaksanakan oleh pemerintah yaitu imunisasi rutin yang terdiri dari imunisasi dasar dan imunisasi lanjutan. Imunisasi dasar dan lanjutan yang diwajibkan oleh pemerintah adalah imunisasi campak. Imunisasi campak mendapat perhatian lebih dari pemerintah karena Indonesia ikut serta dalam program eliminasi campak pada tahun 2020 dengan cakupan campak minimal 95\% di setiap wilayah secara merata. (Kemenkes RI, 2017).

Kemenkes RI (2010) menjelaskan terkait cakupan imunisasi itu berhubungan erat dengan pengetahuan dan sikap keluarga akan manfaat dari imunisasi. Semakin tinggi pengetahuan dan sikap semakin tinggi pula angka cakupannya. Dan yang menjadi permasalahan saat yaitu ketepatan pemberian imunisasi. Hal ini bisa memperlambat terbentuknya sistem imunitas pada bayi secara cepat, sehingga dengan mudah bayi akan terkena penyakit campak. Walaupun campak itu sudah masuk dalam program imunisasi nasional pada tahun 1982, masih saja ditemukan kejadian luar biasa (KLB) campak. Hal ini disebabkan adanya akumulasi anak- anak rentan ditambah $15 \%$ anak yang tidak terbentuk imunitasnya (Ditjen P2PL Depkes RI, 2008). Dan hal lain juga dari pihak masyarakat itu sendiri masih ada yang menolak imunisasi karena takut ada efek samping (kejadian ikutan pasca imunisasi). Sedangkan vaksin campak itu tergolong aman, walaupun dapat menimbulkan reaksi pada sebagian kecil anak, tapi itu jarang bersifat serius. Reaksi dapat berupa ruam - ruam kulit ringan, demam ringan, pilek adalah reaksi yang paling umum ditemui setelah imunisasi dan dapat diobati. (Tjandra, 2009).

Beberapa penelitian menemukan bahwa kepercayaan dan perilaku kesehatan ibu mempunyai peranan yang sangat besar dalam program imunisasi dasar. Perilaku kesehatan tersebut merupakan suatu respon yang ditunjukkan ibu terhadap rangsangan yang berasal dari luar maupun dari dalam diri ibu itu sendiri dan dapat dipengaruhi oleh beberapa faktor (Notoatmodjo, 2012).

Perilaku kesehatan seseorang dapat dipengaruhi oleh beberapa faktor yaitu faktor predisposisi yang meliputi pengetahuan, sikap, pendidikan, kepercayaan masyarakat, sosial, budaya dan tingkat ekonomi. Perilaku seseorang akan ditentukan oleh sikap dan sikap sangat dipengaruhi oleh pengetahuan. Pengetahuan adalah domain yang sangat penting untuk terbentuknya tindakan seseorang. Pengetahuan adalah hasil penginderaan manusia atau hasil tahu seseorang terhadap objek melalui indera yang dimilikinya (mata, hidung, telinga, dan sebagainya). Waktu penginderaan sampai menghasilkan pengetahuan tersebut sangat dipengaruh oleh intensitas persepsi terhadap objek. Sebagian besar pengetahuan seseorang melalui indera pendengaran (telinga) dan indera penglihatan (mata) (Notoatmodjo, 2010). Perubahan hubungan antara orangtua dengan anak sudah dimulai pada usia 2 tahun dan 
terus berlangsung hingga awal kanak-kanak dan berlangsung relatif cepat. Karena anak sangat tergantung kepada orangtuanya, terutama yang berkaitan dengan pemenuhan kebutuhan, rasa aman dan kebahagiaan, maka adanya hubungan yang buruk antara orangtua terutama ibu dengan anak akan berakibat buruk dalam perkembangan sosial anak dimasa yang akan datang (Hurlock 1980 dalam Janiwarty 2015).

Oleh karena itu pemahaman dan keikutsertaan ibu dalam program imunisasi ini tidak akan menjadi halangan yang besar jika ibu mempunyai perilaku kesehatan yang baik (Notoatmodjo, 2012).

Berdasarkan laporan dari Dinas Kesehatan Kabupaten Ciamis tahun 2019 untuk imunisasi campak belum seluruhnya tercapai sesuai target. Puskesmas Cipaku merupakan Puskesmas ke 2 yang cakupannya terendah setelah Puskesmas Kawalimukti yaitu hanya $(87,3 \%)$ dari target ketercapaian (95\%). Yang mana Puskesmas Cipaku untuk letak geografisnya lebih dekat dengan perkotaan, dimana seharusnya angka ketercapaian bisa sesuai target melihat pengetahuan didaerah dekat perkotaan lebih mudah mendapat edukasi. Fenomena ini dapat dimengerti karena antara perkotaan dan pedesaan memang terdapat perbedaan dalam fasilitas umum yang tersedia disamping juga dalam karakteristik penduduk salah satunya adalah fasilitas kesehatan yang berbeda antara perkotaan dan pedesaan akan tetapi di Puskesmas Cipaku belum mencapai target dilihat di daerah itu dekat perkotaan.

Data Puskesmas Cipaku di dapatkan kurangnya ketercapaian imunisasi campak dari sasaran 685 bayi yang tercapai 598 bayi dan untuk kasus campak di Wilayah Kerja Puskesmas Cipaku pada tahun 2017 ada 45 kasus dan pada tahun 2018 ada 40. Dari studi pendahuluan yang dilaksanakan di Wilayah Kerja Puskesmas Cipaku dengan wawancara terhadap $10 \mathrm{ibu}$ bayi, ada 4 yang tidak tahu definisi imunisasi, 3 tidak tahu tentang manfaat dan dampak tidak diimunisasi, 3 tidak tahu jadwal imunisasi dan takut anaknya sakit dan panas. Oleh karena itu penulis tertarik untuk melakukan penelitian hubungan tingkat pengetahuan ibu tentang imunisasi campak dengan ketercapaian imunisasi campak pada bayi di Wilayah Kerja Puskesmas Cipaku Kabupaten Ciamis Tahun 2020.

\section{METODE PENELITIAN}

Penelitian ini menggunakan desain penelitian deskriptif korelasi dengan pendekatan cross sectional, jenis penelitian ini tujuannya untuk menemukan ada atau tidaknya hubungan antar variabel. Penelitian cross sectional adalah jenis penelitian yang menekankan waktu yang relatif singkat dilakukan dalam satu waktu. Penelitian ini digunakan untuk mengetahui hubungan antara variabel independen dan dependen dengan metode yang dilakukan dengan cara survei, kuesioner dan wawancara (Donsu, 2019). Penelitian ini yaitu untuk mengidentifikasi tingkat pengetahuan ibu terhadap ketercapaian imunisasi campak pada bayi di Wilayah Kerja Puskesmas Cipaku Kabupaten Ciamis. Penelitian dilakukan hanya pada satu periode tertentu dan pengambilan sample dilakukan dalam sekali waktu saja, tidak ada pengulangan dalam pengambilan data, dimana responden hanya mendapat satu kali kesempatan untuk menjadi responden.

\section{HASIL PENELITIAN}

Analisa Univariat

1. Gambaran tingkat pengetahuan ibu yang mempunyai bayi tentang imunisasi campak di Wilayah Kerja Puskesmas Cipaku Kabupaten Ciamis Tahun 2020.

Tabel 1

Distribusi Frekuensi Tingkat Pengetahuan Ibu Yang Mempunyai Bayi Tentang Imunisasi Campak di Wilayah Kerja Puskesmas Cipaku Kabupaten Ciamis

\begin{tabular}{lccc} 
No & Pengetahuan & F & $\%$ \\
\hline 1. & Baik & 45 & 51,1 \\
2. & Cukup & 23 & 26,1 \\
3. & Kurang & 20 & 22,7 \\
\hline Jumlah & & 88 & 100
\end{tabular}

Berdasarkan tabel 1 diketahui bahwa tingkat pengetahuan ibu yang mempunyai bayi tentang imunisasi campak di Wilayah Kerja Puskesmas Cipaku Kabupaten Ciamis, sebagian besar ibu memiliki pengetahuan yang baik tentang imunisasi campak sebanyak 45 orang $(51,1 \%)$, hampir sebagian ibu memiliki pengetahuan 
cukup tentang imunisasi campak sebanyak 23 orang $(26,1 \%)$ dan sebagian kecil ibu memiliki pengetahuan yang kurang tentang imunisasi campak yaitu sebanyak 20 orang $(22,7 \%)$.

2. Ketercapaian imunisasi campak pada bayi di Wilayah Kerja Puskesmas Cipaku Kabupaten Ciamis Tahun 2020

Tabel 2

Distribusi Frekuensi Ketercapaian Imunisasi Campak

Pada Bayi di Wilayah Kerja Puskesmas Cipaku Kabupaten Ciamis

\begin{tabular}{lccc} 
No & $\begin{array}{c}\text { Ketercapaian Imunisasi } \\
\text { Campak }\end{array}$ & F & $\%$ \\
\hline 1. & Tidak Diimunisasi & 27 & 30,7 \\
2. & Diimunisasi & 61 & 69,3 \\
\hline Jumlah & & 88 & 100
\end{tabular}

Berdasarkan tabel 2 diketahui bahwa ketercapaian imunisasi campak pada bayi di Wilayah Kerja Puskesmas Cipaku Kabupaten Ciamis Tahun 2020, sebagian besar bayi mendapatkan imunisasi campak yaitu sebanyak 61 orang $(69,3 \%)$ dan hampir sebagian bayi tidak mendapatkan imunisasi campak yaitu sebanyak 27 orang $(30,7 \%)$.

\section{Analisa Bivariat}

Tabel 3

Distribusi Frekuensi Hubungan Tingkat Pengetahuan Ibu Tentang Imunisasi Campak Dengan Ketercapaian Imunisasi Campak Pada Bayi di Wilayah Kerja Puskesmas Cipaku Kabupaten Ciamis

\begin{tabular}{ccccccccc} 
& \multicolumn{9}{c}{ Ketercapaian Imunisasi Campak } & \multirow{2}{*}{ Total } & \multirow{2}{*}{$\chi^{2}$ hitung } & \multirow{2}{*}{$\rho$ value } \\
\cline { 2 - 6 } Pengetahuan Ibu & \multicolumn{2}{c}{ Tidak Diimunisasi } & Diimunisasi & & & \\
\cline { 2 - 6 } & $\mathrm{F}$ & $\%$ & $\mathrm{~F}$ & $\%$ & $\mathrm{~F}$ & $\%$ & & \\
\hline Baik & 2 & 4,4 & 43 & 95,6 & 45 & 51,1 & & \\
Cukup & 8 & 34,8 & 15 & 65,2 & 23 & 26,1 & \multirow{2}{*}{42,493} & 0,000 \\
Kurang & 17 & 85 & 3 & 15 & 20 & 22,7 & &
\end{tabular}

Berdasarkan tabel 4.3 diatas menunjukan dari 45 orang ibu yang berpengetahuan baik hampir seluruhnya yaitu sebanyak 43 orang (95,6\%) bayinya diimunisasi campak dan sebagian kecil dari responden yaitu 2 orang $(4,4 \%)$ bayinya tidak diimunisasi campak, dari 23 orang ibu yang berpengetahuan cukup sebagian besar reponden yaitu sebanyak 15 orang $(65,2 \%)$ bayinya diimunisasi campak dan hampir sebagian responden yaitu 8 orang $(34,8 \%)$ bayinya tidak diimunisasi campak, dan dari 20 orang ibu yang berpengetahuan kurang hampir seluruhnya yaitu sebanyak 17 orang $(85 \%)$ bayinya tidak diimunisasi campak dan sebagian kecil responden yaitu 3 orang (15\%) bayinya diimunisasi campak.

Dari hasil analisa data diperoleh nilai chi square $\left(\chi^{2}\right)$ sebesar 42,493 dan nilai $\rho$ value sebesar 0,000. Berdasarkan hasil analisa data di atas maka dapat disimpulkan bahwa terdapat hubungan yang signifikan antara tingkat pengetahuan ibu tentang imunisasi campak dengan ketercapaian imunisasi campak pada bayi di Wilayah Kerja Puskesmas Cipaku Kabupaten Ciamis Tahun 2020 karena nilai $\rho$ value $<\alpha(0,000$ $<0,05)$ dan nilai chi square $\left(\chi^{2}\right)$ hitung $>$ chi square $\left(\chi^{2}\right)$ tabel $(42,493>5,991)$, yaitu semakin baik pengetahuan ibu maka semakin tinggi ketercapaian imunisasi campak dan sebaliknya semakin kurang pengetahuan ibu maka semakin rendah ketercapaian imunisasi campak.

\section{PEMBAHASAN}

Analisa Univariat

\section{Gambaran Tingkat Pengetahuan Ibu Yang Mempunyai Bayi Tentang.Imunisasi Campak di Wilayah Kerja Puskesmas Cipaku Kabupaten Ciamis}

Berdasarkan hasil penelitian bahwa tingkat pengetahuan ibu yang mempunyai bayi tentang imunisasi campak di Wilayah Kerja Puskesmas Cipaku Kabupaten Ciamis, sebagian besar ibu 
memiliki pengetahuan yang baik tentang imunisasi campak sebanyak 45 orang $(51,1 \%)$. Berdasarkan wawancara singkat dengan bidan desa setempat bahwa pengetahuan baik yang dimiliki ibu disebabkan karena ibu aktif mencari informasi tentang imunisasi dasar baik melalui media cetak, media elektronik dan memahami dengan baik dari penjelasan ataupun penyuluhan yang diberikan oleh petugas kesehatan setempat. Pengetahuan Ibu yang baik tentang imunisasi campak juga disebabkan oleh sebagian besar ibu memiliki riwayat pendidikan SMA sederajat sehingga pengetahuan yang diperoleh dapat menyerap dan mendengarkan penjelasan yang disampaikan oleh petugas posyandu dengan berperilaku melaksanakan imunisasi campak untuk bayinya.

Hal ini sesuai dengan teori yang dikemukakan Notoatmodjo (2012) bahwa pendidikan adalah upaya untuk memberikan pengetahuan sehingga terjadi prilaku positif yang meningkat, dalam hal ini mengenai perilaku dalam pemberian imunisasi dasar bagi bayinya.

Notoatmodjo (2012) mendefinisikan bahwa pengetahuan adalah suatu hasil dari tahu yang terjadi setelah seseorang melakukan penginderaan terhadap suatu objek tertentu, melalui indera penglihatan, pendengaran, penciuman, perasaan dan perabaan. Dan sebagian besar pengetahuan manusia diperoleh melalui penglihatan dan pendengaran, hanya sedikit yang diperoleh melalui penciuman, perasaan dan perabaan. Pengetahuan atau kognitif merupakan domain yang sangat penting bagi terbentuknya suatu tindakan-tindakan yang didasari oleh pengetahuan akan lebih baik daripada tindakan yang tidak didasari oleh pengetahuan.

Pengetahuan ibu dapat diperoleh dari pendidikan atau pengamatan serta informasi yang didapat seseorang. Pengetahuan dapat menambah ilmu dari seseorang serta merupakan proses dasar dari kehidupan manusia. Melalui pengetahuan, manusia dapat melakukan perubahan-perubahan kualitatif individu sehingga tingkah lakunya berkembang (Slamet, 2018).

Selain itu hampir sebagian ibu memiliki pengetahuan cukup tentang imunisasi campak sebanyak 23 orang $(26,1 \%)$ dan sebagian kecil ibu memiliki pengetahuan yang kurang tentang imunisasi campak yaitu sebanyak 20 orang
$(22,7 \%)$. Pengetahuan Ibu yang cukup tentang imunisasi campak juga disebabkan oleh sebagian besar ibu memiliki riwayat pendidikan SMP sederajat dan pengetahuan ibu yang kurang tentang imunisasi campak disebabkan oleh sebagian besar ibu memiliki riwayat pendidikan SD sederajat sehingga pengetahuan yang diperoleh kurang dapat menyerap dan mendengarkan penjelasan yang disampaikan oleh petugas posyandu dengan melaksanakan perilaku dalam pemberian imunisasi campak bagi bayinya.

2. Gambaran Ketercapain Imunisasi Campak Pada Bayi di Wilayah Kerja Puskesmas Cipaku

Kabupaten Ciamis Tahun 2020

Dari hasil penelitian menunjukkan bahwa ketercapaian imunisasi campak pada bayi di Wilayah Kerja Puskesmas Cipaku Kabupaten Ciamis Tahun 2020, sebagian besar bayi mendapatkan imunisasi campak yaitu sebanyak 61 orang $(69,3 \%)$. Hal ini disebabkan karena ibu memiliki pengetahuan yang baik mengenai kelengkapan imunisasi sehingga mempengaruhi kesadaran ibu akan pentingnya pemberian imunisasi campak pada bayi. Namun hampir sebagian bayi tidak mendapatkan imunisasi campak yaitu sebanyak 27 orang $(30,7 \%)$, hal ini disebabkan masih ada ibu yang merasa takut dan enggan membawa anaknya untuk imunisasi ke posyandu karena mereka beranggapan bahwa pemberian imunisasi dapat mengakibatkan bayinya menjadi sakit.

Hal ini sesuai dengan teori yang dikemukakan oleh Ali (2015) bahwa pengetahuan, kepercayaan, dan perilaku kesehatan seorang ibu akan mempengaruhi kepatuhan pemberian imunisasi campak pada bayi dan anak, sehingga dapat mempengaruhi status imunisasinya. Masalah pengertian, pemahaman dan kepatuhan ibu dalam program imunisasi bayinya tidak akan menjadi halangan yang besar jika pendidikan dan pengetahuan yang memadai tentang hal itu diberikan.

Kelengkapan imunisasi dasar anak sangat berpengaruh terhadap tumbuh kembang anak. Dengan memberikan imunisasi secara lengkap kepada anaknya, dapat mengurangi resiko kesakitan dan kematian pada anak/bayinya. Karena imunisasi merupakan suatu proses atau tindakan memberi kekebalan pada bayi/anak dengan cara 
memasukan vaksin ke dalam tubuh dengan tujuan agar tubuh terlindung dari penyakit tertentu (Iriannie, 2015).

\section{Analisa Bivariat}

Berdasarkan hasil penelitian menunjukan dari 45 orang ibu yang berpengetahuan baik hampir seluruhnya yaitu sebanyak 43 orang (95,6\%) bayinya diimunisasi campak dan sebagian kecil dari responden yaitu 2 orang $(4,4 \%)$ bayinya tidak diimunisasi campak, dari 23 orang ibu yang berpengetahuan cukup sebagian besar reponden yaitu sebanyak 15 orang $(65,2 \%)$ bayinya diimunisasi campak dan hampir sebagian responden yaitu 8 orang $(34,8 \%)$ bayinya tidak diimunisasi campak, dan dari 20 orang ibu yang berpengetahuan kurang hampir seluruhnya yaitu sebanyak 17 orang (85\%) bayinya tidak diimunisasi campak dan sebagian kecil responden yaitu 3 orang (15\%) bayinya diimunisasi campak.

Dari hasil analisa data diperoleh nilai chi square $(\chi 2)$ sebesar 42,493 dan nilai $\rho$ value sebesar 0,000. Berdasarkan hasil analisa data di atas maka dapat disimpulkan bahwa terdapat hubungan yang signifikan antara tingkat pengetahuan ibu tentang imunisasi campak dengan ketercapaian imunisasi campak pada bayi di Wilayah Kerja Puskesmas Cipaku Kabupaten Ciamis Tahun 2020 karena nilai $\rho$ value $<\alpha(0,000$ $<0,05)$ dan nilai chi square $(\chi 2)$ hitung $>$ chi square $(\chi 2)$ tabel $(42,493>5,991)$, yaitu semakin baik pengetahuan ibu maka semakin tinggi ketercapaian imunisasi campak dan sebaliknya semakin kurang pengetahuan ibu maka semakin rendah ketercapaian imunisasi campak.

Berdasarkan hasil penelitian berpengetahuan baik hampir seluruh bayinya membawa anaknya untuk di imunisasi, hal ini disebabkan karena ibu tidak sibuk bekerja, memiliki waktu luang, dan memiliki pengetahuan baik tentang imunisasi dan memperhatikan kesehatan bayinya. Selain itu terdapat responden yang memiliki pengetahuan baik bayinya tidak diimunisasi, hal ini disebabkan karena kesibukan responden dalam bekerja sehingga responden tidak memiliki waktu luang untuk mambawa bayinya diimunisasi.

Berdasarkah hasil penelitian ibu yang berpengetahuan kurang hampir seluruh bayinya tidak diimunisasi campak hal ini disebabkan karena ibu merasa takut dan enggan membawa anaknya untuk imunisasi ke posyandu karena mereka beranggapan bahwa pemberian imunisasi dapat mengakibatkan bayinya menjadi sakit. Selain itu terdapat responden yang memiliki pengetahuan kurang tetapi bayinya diimunisasi, hasil ini disebabkan responden tersebut bekerja sebagai ibu rumah tangga sehingga seorang ibu cenderung memiliki waktu yang luang membawa bayinya ke Posyandu untuk mendapatkan imunisasi campak.

Adanya variasi pengetahuan dalam penelitian ini dipengaruhi oleh adanya faktor perbedaan karakteristik responden, yaitu: Pertama, faktor usia. Dari penelitian menunjukkan bahwa responden baru umur $>30$ tahun sebanyak 52\%. Semakin cukup umur, tingkat kematangan dan kekuatan seseorang akan lebih matang dalam berfikir dan sebagai pengalaman. Hal ini yang menyebabkan pengetahuan responden baik tentang imunisasi campak. Kedua, faktor tingkat pendidikan. Berdasarkan penelitian diatas dapat diketahui bahwa sebagian besar responden sebanyak $64 \%$ berpendidikan SMA sederajat. Pendidikan menentukan mudah tidaknya seseorang meyerap dan memahami pengetahuan yang mereka miliki maupun peroleh, pada umumnya semakin tinggi pendidikan seseorang akan semakin baik pula pengetahuannya. Sehingga hal ini biasa disebabkan karena pendidikan yang dimiliki oleh responden baik sehingga mereka mampu dalam menerima dan menyerap informasi yang telah mereka peroleh. Faktor berikutnya adalah pekerjaan. Berdasarkan penelitian diatas dapat diketahui bahwa $67 \%$ bekerja hanya sebagai Ibu rumah tangga. Pekerjaan merupakan faktor yang mempengaruhi pengetahuan seseorang. Ditinjau dari jenis pekerjaan yang interaksi dengan orang lain lebih banyak pengetahuannya bila di bandingkan dengan orang tanpa interaksi dengan orang lain. Pengalaman belajar dalam bekerja yang dikembangkan memberikan pengetahuan dan ketrampilan professional serta pengalaman belajar dalam bekerja akan dapat mengembangkan kemampuan dalam mengambil keputusan yang merupakan keterpaduan menalar secara ilmiah dan etik. Sehingga pada penelitian ini responden tidak banyak memiliki waktu untuk bertukar pikiran tentang imunisasi campak dan pemberiannya..

Hasil penelitian ini sesuai dengan penelitian yang dilakukan oleh Kamidah (2013) mengenai hubungan Antara tingkat pengetahuan imunisasi 
dengan perilaku ibu terhadap imunisasi bayi di Puskesmas Gondokusuman II Yogyakarta. Hasil dari penelitian Kamidah diperoleh bahwa ada hubungan yang signifikan antara tingkat pengetahuan imunisasi dengan perilaku ibu terhadap imunisasi bayi. Hal ini berarti bahwa sebagian besar pengetahuan ibu tentang imunisasi dapat mempengaruhi perilaku ibu terhadap pemberian imunisasi bagi bayinya. Hasil tersebut sesuai dengan teori Notoatmodjo (2015) bahwa pengetahuan merupakan faktor yang sangat penting untuk terbentuknya suatu sikap dan tindakan seseorang karena dari pengalaman dan penelitian terbukti bahwa perilaku yang didasarkan dengan pengetahuan akan lebih berpengaruh dan menimbulkan kesadaran dalam diri dibandingkan dengan tidak didasarkan oleh pengetahuan.

Hasil penelitian ini sesuai dengan penelitian yang dilakukan oleh Momomuat, dkk (2015) dengan judul "Hubungan Tingkat Pengetahuan Ibu Tentang Pentingnya Imunisasi Campak Dengan Kepatuhan Melaksanakan Imunisasi Di Puskesmas Kawangkoan". Hasil penelitian ini menunjukkan bahwa semakin tinggi tingkat pengetahuan ibu tentang imunisasi, maka akan semakin baik pula perilaku dalam melaksanakan imunisasi bagi anaknya. Sebaliknya apabila tingkat pengetahuan ibu tentang imunisasi campak kurang maka perilaku dalam melaksanakan imunisasi campak pada anak akan kurang pula. Hal ini didukung pula oleh penelitian yang dilakukan oleh Triana (2016) dengan judul "Faktor yang Berhubungan dengan Pemberian Imunisasi Dasar pada Bayi di Kecamatan Kuranji Kota Padang”. Hasil penelitian ini menunjukkan bahwa faktor yang mempengaruhi orang tua dalam melaksanakan pemberian imunisasi pada anaknya tidak hanya dipengaruhi oleh faktor tingkat pengetahuan ibu akan tetapi ada faktor lain yang mempengaruhi seperti tingkat pendidikan, sikap, usia, pekerjaan, kesehatan bayi, dan dukungan tenaga kesehatan. Orang yang memiliki pengetahuan yang baik tentang sesuatu hal maka orang tersebut akan mengaplikasikan pengetahuannya tersebut dalam kehidupannya sehari-hari, karena pengetahuan merupakan tonggak domain yang mempengaruhi seseorang dalam bertindak dan berperilaku.

Berdasarkan hasil tersebut maka pengetahuan ibu tentang imunisasi dasar dapat mempengaruhi prilaku ibu dalam pemberian imunisasi dasar. Hasil Penelitian ini sesuai dengan teori yang dikemukakan Notoatmodjo (2012) yang menyatakan bahwa pengetahuan merupakan domain yang sangat penting dalam pembentukan perilaku dan perilaku ini ditentukan oleh faktor predisposisi (predispossing factor) yaitu faktorfaktor yang dapat mempermudah atau mempredisposisi terjadinya perilaku pada diri seseorang atau masyarakat, adalah pengetahuan dan sikap seseorang atau masyarakat.

Pengetahuan merupakan domain yang sangat penting bagi terbentuknya suatu tindakan. Tindakan yang didasari oleh pengetahuan akan lebih baik dari pada tindakan yang tidak didasari oleh pengetahuan. Oleh karena itu pengetahuan ibu akan pentingnya imunisasi dasar anak sangat berperan terhadap kesehatan dan kelangsungan hidup anaknya.

\section{SIMPULAN}

Dari hasil analisa penelitian diatas dapat disimpulkan sebagai berikut

1. Gambaran tingkat pengetahuan ibu tentang imunisasi campak pada bayi adalah sebagian besar ibu yang memilki bayi di Wilayah Kerja Puskesmas Cipaku memiliki pengetahuan yang baik sebanyak 45 orang $(51,1 \%)$.

2. Gambaran ketercapaian imunisasi campak pada bayi adalah sebagian besar ibu yang memiliki bayi di Wilayah Kerja Puskesmas Cipaku yang telah diimunisasi campak sebanyak 61 orang $(69,3 \%)$.

3. Terdapat hubungan yang signifikan antara tingkat pengetahuan ibu tentang imunisasi campak dengan ketercapaian imunisasi campak pada bayi di Wilayah Kerja Puskesmas Cipaku Tahun 2020 ditunjukan dengan nilai $p$ value sebesar 0,000 .

\section{DAFTAR PUSTAKA}

Donsu, Jenita. 2019. Metodologi Penelitian Keperawatan. Pustaka Baru Press. Yogyakarta.

Kemenkes RI. 2017. Peraturan Menteri Kesehatan Indonesia Nomor 12 tentang Penyelenggaraan Imunisasi. Kementrian Kesehatan RI. Jakarta.

Notoatmodjo, Soekidjo. 2010. Ilmu Perilaku Kesehatan. Rineka Cipta. Jakarta. 
Jurnal Keperawatan Galuh, Vol.2 No.2 (2020) 53 - 60

WHO. 2015. Meales cased Reported By Country 2015. Dari http//apps.WHO. Into/gho/diakses 8 Maret 2020.

Dinas Kesehatan Ciamis. 2019. Laporan Tahunan Imunisasi Rutin Bayi Komulatif Tahun 2019. Dinas Kesehatan Ciamis. Ciamis. 